\title{
A REVIEW ON HOMOGENEOUS CHARGE COMPRESSION IGNITION ENGINE PERFORMANCE USING BIODIESEL-DIESEL BLEND AS A FUEL
}

\author{
M.M. Hasan, M.M. Rahman, and K. Kadirgama \\ Faculty of Mechanical Engineering, Universiti Malaysia Pahang \\ 26600 Pekan, Pahang, Malaysia \\ E-mail: mustafizur@ump.edu.my \\ Phone: +6094246239; Fax: +6094246222
}

\begin{abstract}
Homogeneous charge compression ignition (HCCI) engines employ a relatively new mode of combustion technology, in which auto-ignition occurs when the lean mixture of air and fuel reaches its chemical activation energy. It is a combustion concept that offers simultaneous reductions in both $\mathrm{NOx}$ and soot emissions from internal combustion engines. A wide range of fuels can be used in this engine. Of these, diesel and biodiesel-diesel blends are most common. The objective of this study is to illustrate the fuel properties, engine performance and emission characteristics of the mentioned fuels at different conditions performed worldwide in HCCI engines, as well as to compare HCCI engines with conventional compression ignition (CI) engines in respect of engine combustion, performance and emission characteristics. This may also introduce a potential guideline to improve engine performance and emission characteristics using diesel and its blends. From the review, it can be said that using diesel and its blends in HCCI engines with biodiesel can improve the overall engine performance and emission characteristics in comparison with CI engines.
\end{abstract}

Keywords: Combustion; diesel; biodiesel; engine performance; HCCI; emission.

\section{INTRODUCTION}

Around the world, internal combustion (IC) engines have become very popular for various purposes. But the emissions produced by these engines are not at a satisfactory level. In order to reduce these emission levels, a new mode of combustion is being sought by engine researchers. In this regard, the homogeneous charge compression ignition (HCCI) combustion mode is one potential solution [1, 2]. HCCI combustion can be defined as a process by which a homogeneous mixture of air and fuel is compressed until auto-ignition occurs near the end of the compression stroke. It is noticeably faster than either compression ignition (CI) or spark ignition (SI) combustion [3]. HCCI technology can improve the thermal efficiency and maintain low emissions and can also be implemented by modifying either SI or CI engines. A wide variety of fuels, combinations of fuels and alternative fuels can be used in this technology $[4,5]$. Usually a lean air-fuel mixture is used in HCCI engines. It ignites automatically in several locations and is then burned volumetrically without visible flame propagation [6]. Once ignited, combustion occurs very quickly and it is fully controlled by chemical kinetics rather than spark or ignition timing [7]. For this reason, it is very difficult to control the auto-ignition of the mixture and the heat release rate at high load operations, to meet emissions standards and control knocking [8,9]. 
The advantages of HCCI technology are as follows: 1) as HCCI engines are fuel-lean, they can operate at diesel-like compression ratios $(>15)$, thus achieving higher efficiencies than conventional SI gasoline engines [10-13]; 2) they can operate on a wide range of fuels $[11,14]$; 3) they can produce a cleaner combustion and lower emissions, and especially NOx levels are almost negligible [15]. On the other hand, HCCI technology has some disadvantages such as high levels of unburned hydrocarbons (UHC) and carbon monoxide (CO) $[8,16,17]$, as well as knocking under certain operating conditions $[8,16]$. The study of the characteristics of fuel plays a significant role in HCCI engines because the performance of this type of engine strongly depends on them. The choice of fuel also affects the emission levels. Sometimes the blending of two fuels improves the properties of the fuel and can ultimately provide better engine performance and emissions. In terms of emissions, diesel engines produce higher levels of NOx and particulate matter [18] or soot, which require proper control strategies because of their negative health and environmental effects. This problem can be solved by using HCCI combustion in IC engines. As HCCI operates on lean mixtures, the peak temperatures are much lower than SI and CI. The low peak temperatures reduce the formation of NOx. However, the low peak temperatures also lead to incomplete burning of fuel, especially near the combustion chamber walls. This leads to high carbon monoxide and hydrocarbon emissions. An oxidizing catalyst can remove the regulated species, because the exhaust is still oxygenrich. Due to the significance of HCCI technology, which can be a replacement for conventional CI or SI engines, there is a need to report on recent advances of this technology. In this study, peer-reviewed articles from highly rated journals on commonly used fuel (diesel and biodiesel-diesel blend) in HCCI engines have been reviewed. This report focuses on the fuel properties, engine performance and emission characteristics of the abovementioned fuel and compares the data with CI engines. Each of them is discussed in detail in different sections. Finally, different research results are presented in tabular form to allow easy comparison among them.

\section{FUEL PROPERTIES}

The proper operation of an engine depends on a number of fuel properties. Viscosity, density, cetane number, heating value, flash point, pour point etc. are the most significant properties of fuel. Engine performance and emission are directly related to these. Before being used as a fuel, it should fulfill the standard limit defined by various standards such as ASTM, EN, ISO, etc. Among these, ASTM is widely used. Fuel whose properties' values lie within the standard limit provides smooth engine performance and emission. In this regard, the study of fuel properties plays an important role when planning to use a liquid as fuel. The blending of two or more fuels has recently become very popular because it improves these fuel properties. In this study, the properties of diesel and biodiesel-diesel blend in a CI engine are discussed. Table 1 presents the fuel properties of the discussed fuel and blend.

\section{Kinematic Viscosity}

Kinematic viscosity is the resistance of liquid to flow. It indicates the thickness of the oil and is traditionally measured by noting the time it takes oil to travel through the orifice of a capillary of a particular size under the force of gravity. It should be lower for better performance of engines because higher viscosity requires the consumption of 
more fuel pumping power as well as leading to poor spray and atomization [19-21]. It also increases fuel consumption [22]. From Table 1 it can be seen that the biodieseldiesel blend has a lower kinematic viscosity than diesel. This ultimately reduces the fuel consumption, in addition to which better spray and atomization can be found.

\section{Density}

Density is a physical property which is used to calculate the precise volume of the fuel necessary to supply an adequate combustion. Density and viscosity are directly proportional to each other. Higher density increases the energy concentration of fuel [23], and the fuel atomization efficiency is also influenced by its density [20]. But higher density causes higher viscosity, which ultimately gives poor combustion and affects engine performance and emission [24]. Usually, biodiesel is denser than diesel fuel, but when it is blended with diesel it reaches a acceptable level which is good for better engine performance. From Table 1 it is seen that the blend's density is slightly higher than diesel.

\section{Cetane Number}

The cetane number $(\mathrm{CN})$ is a measurement of the combustion quality of the fuel used in a compression ignition engine. Thus it is the approximate equivalent of an octane rating for fuel used in a spark ignition engine. It is a dimensionless descriptor. There is a close relation between ignition delay and $\mathrm{CN}$. A higher $\mathrm{CN}$ shortens the ignition delay period. In this regard, a higher $\mathrm{CN}$ is expected. From Table 1 it is seen that the $\mathrm{CNs}$ of both the fuel and blend are similar. Thus, it does not create any difference in engine combustion characteristics.

\section{Calorific Value}

The calorific value of a fuel can be defined as the amount of heat given out by the complete combustion of a unit quantity of that particular fuel. It is an important parameter to determine the suitability of a fuel [25]. Engine combustion characteristics and performance are influenced by the calorific value. It facilitates the heat release during combustion and improves the power output [26-29]. Usually, biodiesel has a lower calorific value than diesel, but when it is blended with diesel it reaches a acceptable level which is good for better engine performance. From Table 1 it is seen that the blend's density is slightly lower than diesel.

Table 1. Fuel properties of ordinary diesel and biodiesel-diesel blend.

\begin{tabular}{lllllllll}
\hline Properties & $\begin{array}{l}\text { Kinematic } \\
\text { viscosity } \\
40^{\circ} \mathrm{C}(\mathrm{cSt})\end{array}$ & $\begin{array}{l}\text { Density } \\
\left(\mathrm{kg} / \mathrm{m}^{3}\right)\end{array}$ & $\begin{array}{l}\text { Cetane } \\
\text { number }\end{array}$ & $\begin{array}{l}\text { Calorific } \\
\text { value } \\
(\mathrm{MJ} / \mathrm{kg})\end{array}$ & $\begin{array}{l}\text { Flash } \\
\text { point } \\
\left({ }^{\circ} \mathrm{C}\right)\end{array}$ & $\begin{array}{l}\text { Pour } \\
\text { point } \\
\left({ }^{\circ} \mathrm{C}\right)\end{array}$ & $\begin{array}{l}\text { Cloud } \\
\text { point } \\
\left({ }^{\circ} \mathrm{C}\right)\end{array}$ & Ref. \\
\hline ASTM limit & $1.9-6$ & --- & $\begin{array}{l}47 \\
\text { minimum }\end{array}$ & --- & $\begin{array}{l}130 \\
\text { minimum }\end{array}$ & --- & --- & \\
$\begin{array}{l}\text { Diesel } \\
\begin{array}{l}\text { Biodiesel-diesel } \\
\text { blend (up to } \\
30 \% \text { biodiesel) }\end{array}\end{array}$ & $2.5-5.7$ & $816-840$ & $45-55$ & $43-47$ & $50-98$ & $-6-5$ & $-16-5$ & {$[30-$} \\
\hline
\end{tabular}




\section{Flash Point}

The flash point can be defined as the temperature of fuel at which it will ignite when exposed to a flame or spark. It has an inverse relation with the fuel's volatility. The flash point has great importance because it directly affects the transportation, storage and handling of fuel. A fuel which has a higher flash point provides safer storage and transport [39]. According to Table 1, the biodiesel-diesel blend has a higher flash point than ordinary diesel, which indicates that the blend is a safer fuel.

\section{Pour Point}

The pour point can be defined as the lowest temperature of a liquid at which it can flow. When the temperature of a fluid reaches its pour point, it becomes semi-solid and ultimately loses its flow characteristics, which causes major operability problems [40]. Considering this matter, a higher pour point is expected. As per Table 1, the pour point of the blend is slightly higher than diesel, which is good for engine operation.

\section{Cloud Point}

The cloud point is a significant property of fuel for low temperature applications. It is defined as the temperature at which dissolved solids are no longer completely soluble, participating as a second phase giving the fluid a cloudy appearance. In this regard a higher cloud point is desirable. According to Table 1, the biodiesel-diesel blend has a higher cloud point than ordinary diesel, which is good for engine performance.

\section{COMBUSTION CHARACTERISTICS}

The engine performance and emission characteristics are directly affected by the combustion characteristics of a fuel. The important parameters that indicate the combustion process effectiveness are in-cylinder pressure, ignition delay, combustion duration, heat release and cumulative heat release rate [41, 42]. In-cylinder pressure can be measured directly from the engine and the other combustion parameters can be calculated from the in-cylinder pressure. The heat release rate is estimated from the first law of thermodynamics using the in-cylinder pressure and the geometry of the crank and connecting rod [43]. The other important combustion parameters can be easily estimated from the heat release rate variation over an engine cycle. This paper illustrates the combustion characteristics of ordinary diesel and biodiesel-diesel blend in HCCI engines, as well as comparing the results with conventional CI engines. Articles reviewed here reveal that HCCI engines produce higher cylinder pressure and heat release as well as shorter ignition delay.

\section{Cylinder Pressure}

The in-cylinder pressure measurement is considered to be a very valuable source of information during the development and calibration stages of the engine. The incylinder pressure signal can provide vital information such as peak pressure, $\mathrm{P}-\mathrm{V}$ diagram, indicated mean effective pressure, fuel supply effective pressure, heat release rate, combustion duration, ignition delay and so on [44]. Moreover, based on ideal gas and the first law of thermo-dynamics, it can be used in more complex calculations, for 
example, in air mass flow estimation, combustion diagnosis and NOx prediction [45]. An HCCI engine usually produces a higher cylinder pressure which in turn gives higher efficiency. However, too much pressure is a problem because it may damage the engine cylinder. From Table 2 it is seen that using diesel in an HCCI engine gives a higher cylinder pressure than a conventional CI engine. This pressure can be reduced to a moderate level by blending biodiesel with diesel. Table 3 indicates that proper utilization of biodiesel-diesel blend can minimize the cylinder pressure.

\section{Ignition Delay}

One of the most important parameters in the combustion phenomenon is the ignition delay. The ignition delay for any fuel can be calculated based on the time elapsed between the start of fuel injection and the start of combustion [46]. Ignition delay strongly depends on the type of fuel used and its concentration in the cylinder charge. The associated changes in the charge temperature during compression, pre-ignition energy release, external heat transfer to the surroundings and the contribution of residual gases appear to be the main factors responsible for controlling the length of the ignition delay of the engine [47]. The physical and chemical properties of the fuels will affect the ignition delay period, and researchers have stressed that chemical properties are much more important than physical properties. The ignition quality of a fuel is usually characterized by its cetane number. A higher cetane number generally means a shorter ignition delay. In this regard, from Table 1 it is seen that diesel has a higher cetane number than its blend. So this shortens the ignition delay period. Tables 2 and 3 show that using diesel in an HCCI engine gives a shorter ignition delay period than in a conventional CI engine, rather than using biodiesel-diesel blend.

\section{Heat Release}

In a typical IC engine, combustion occurs via a flame. Hence at any point in time, only a fraction of the total fuel is burning. This results in low heat release rates. In HCCI, however, the entire fuel/air mixture ignites and burns over a much smaller time interval, resulting in high heat release rates. To withstand the higher heat release, the engine has to be structurally stronger. Several strategies have been proposed to lower the rate of combustion. Mixing fuels with different auto-ignition properties can lower the combustion speed [48]. An HCCI engine usually releases more heat, which sometimes poses challenges in controlling the combustion rates and affects safety and the structural integrity of the engine. From Table 2 it is seen that using diesel in an HCCI engine gives a higher heat release than a conventional CI engine. This heat can be reduced to a moderate level by blending biodiesel with diesel. Table 3 indicates that proper utilization of the biodiesel-diesel blend can minimize the heat release.

\section{PERFORMANCE CHARACTERISTICS}

Engine performance is the next parameter that indicates whether an engine is widely acceptable or not. Brake power, brake specific fuel consumption (BSFC) and brake thermal efficiency are the performance indicators for engines. Not only fuel properties but also fuel injection pressure and timing, the air-fuel mixture, amount of injected fuel, fuel spray pattern etc. affect engine performance. Usually engine brake power, brake torque and BSFC are tested against load or speed. This paper illustrates the performance 
characteristics of ordinary diesel and biodiesel-diesel blend in HCCI engines as well as comparing the result with conventional CI engines. The articles reviewed here reveal that HCCI engines produce lower brake thermal efficiency and that brake specific fuel consumption is higher than in the conventional CI engine.

\section{Break Thermal Efficiency}

The brake thermal efficiency (BTE) of an engine is the ratio of brake output power to input power and describes the brake power produced by an engine with respect to the energy supplied by the fuel. It is a significant characteristic to measure the engine performance. It is clear from Table 2 that using diesel in an HCCI engine does not provide a satisfactory brake thermal efficiency. It is always lower than CI engines. This phenomenon can be changed by using a biodiesel-diesel blend, which can provide higher brake thermal efficiency [49].

\section{Brake Specific Fuel Consumption}

Brake-specific fuel consumption (BSFC) is the ratio between mass fuel consumption and brake effective power and it is inversely proportional to thermal efficiency for a given fuel. It is a measure of the fuel efficiency of any prime mover that burns fuel and produces rotational, or shaft, power. It is typically used for comparing the efficiency of internal combustion engines with a shaft output. From Table 2 and 3 it is clear that in the case of brake specific fuel consumption HCCI engines always lag behind CI engines.

\section{EMISSION CHARACTERISTICS}

Emissions levels have become a major focus in new engine developments nowadays because regulatory bodies, such as those in Europe, the United States and Japan, are imposing stringent vehicle emissions quality standards [50-52]. Emissions in HCCI engines consist of UHC, $\mathrm{CO}, \mathrm{NOx}$, and smoke. HCCI engines are claimed to have low emissions levels of NOx and smoke and high levels of unburned hydrocarbons (HC) and carbon monoxide (CO). However, emissions levels vary from one engine to another and are dependent on the operating conditions of the engine, fuel quality and the engine design [53]. Thus, the emissions levels from one engine cannot be directly compared with another engine. This paper illustrates the emission characteristics of ordinary diesel and biodiesel-diesel blend in HCCI engines as well as comparing the results with conventional CI engines. The articles reviewed here reveal that HCCI engines produce very much lower NOx and smoke as well as higher $\mathrm{HC}$ and $\mathrm{CO}$.

\section{NOx Emission}

Since HCCI engines typically operate fuel-lean, the final flame temperature is usually well below $2000 \mathrm{~K}$. At this low post-combustion temperature, chemical reactions that produce oxides of nitrogen (NOx) are essentially inactive. NOx is generally formed in a high temperature reaction, where the nitrogen in air dissociates into nitrogen radicals to form $\mathrm{NO}$ when reacting with oxygen. Some $\mathrm{NO}$ is converted to $\mathrm{NO}_{2}$ when further reactions occur in the chamber. The HCCI engine has been proven successfully as a low NOx producing engine. Its NOx producing rate is very much lower than conventional 
CI engines. Tables 2 and 3 show that in almost every case NOx production is lower than in diesel engines.

Table 2. Different experimental engine performance and emission results using ordinary diesel in HCCI engine compared to CI engine.

\begin{tabular}{|c|c|c|c|c|}
\hline Engine & Test condition & Performance & Emission & Reference \\
\hline $\begin{array}{l}\text { 1-cylinder, } 4 \text { S, } \\
\text { AC, CI, DI, } \\
\text { CR: 17.5:1, RP: } \\
4.4 \mathrm{~kW}, \mathrm{RS}: \\
1500 \mathrm{rpm}\end{array}$ & $\begin{array}{l}\text { Constant speed, } \\
\text { different loads and } \\
\text { different } \\
\text { percentages of } \\
\text { EGR }(0 \% \text { and } \\
10 \%)\end{array}$ & $\begin{array}{l}\downarrow \text { : Ignition delay, } \\
\text { BTE }\end{array}$ & $\begin{array}{l}\downarrow: \text { NOx, Smoke } \\
\uparrow: \mathrm{HC}, \mathrm{CO}\end{array}$ & {$[54]$} \\
\hline $\begin{array}{l}\text { 2-cylinder, } 4 \text { S, } \\
\text { AC, CI, DI, } \\
\text { CR: 16.5:1, RP: } \\
4.85 \mathrm{~kW}, \mathrm{RS}: \\
1500 \mathrm{rpm}\end{array}$ & $\begin{array}{l}\text { Constant speed, } \\
\text { different loads and } \\
\text { different } \\
\text { percentages of } \\
\text { EGR }(0 \%, 10 \% \\
\text { and } 20 \%)\end{array}$ & $\begin{array}{l}\downarrow: \text { Combustion } \\
\uparrow: \text { Heat release, } \\
\text { combustion duration }\end{array}$ & $\downarrow:$ NOx & [55] \\
\hline $\begin{array}{l}\text { 1-cylinder, 4S, } \\
\text { AC, CI, DI, } \\
\text { CR: 17.5:1, RP: } \\
4.4 \mathrm{~kW}, \mathrm{RS}: \\
1500 \mathrm{rpm}\end{array}$ & $\begin{array}{l}\text { Constant speed, } \\
\text { different loads and } \\
\text { different } \\
\text { percentages of } \\
\text { EGR }(0 \%, 10 \% \text {, } \\
20 \% \text { and } 30 \%)\end{array}$ & $\begin{array}{l}\downarrow \text { : BTE, combustion, } \\
\text { peak pressure }\end{array}$ & $\begin{array}{l}\downarrow: \text { NOx, Smoke } \\
\uparrow: \mathrm{HC}, \mathrm{CO}\end{array}$ & {$[56]$} \\
\hline $\begin{array}{l}\text { 1-cylinder, 4S, } \\
\text { NA, CI, DI, } \\
\text { CR: } 18.5: 1, \text { RS: } \\
1800 \mathrm{rpm}\end{array}$ & $\begin{array}{l}\text { Constant speed } \\
\text { and different loads }\end{array}$ & $\begin{array}{l}\downarrow: \text { ITE } \\
\uparrow: \text { IMEP, cylinder } \\
\text { pressure, heat } \\
\text { release }\end{array}$ & $\begin{array}{l}\downarrow: \text { NOx, } \\
\uparrow: \text { UHC, CO } \\
- \text { : Soot }\end{array}$ & {$[57]$} \\
\hline $\begin{array}{l}\text { 1-cylinder, 4S, } \\
\text { CI, DI, CR: } \\
15: 1, \quad \text { RS: } \\
1500 \mathrm{rpm}\end{array}$ & $\begin{array}{l}\text { Constant speed } \\
\text { and different loads }\end{array}$ & $\downarrow:$ IMEP & $\downarrow:$ NOx, HC & {$[58]$} \\
\hline $\begin{array}{l}\text { 1-cylinder, } 4 \text { S, } \\
\text { WC, NA, CI, } \\
\text { CR: } 14.8: 1\end{array}$ & $\begin{array}{l}\text { Variable speed } \\
\text { and different } \\
\text { percentages of } \\
\text { EGR }(0 \%, 29 \% \text {, } \\
42 \% \text { and } 50 \%)\end{array}$ & $\begin{array}{l}\downarrow: \text { Cylinder pressure } \\
\uparrow: \text { ISFC }\end{array}$ & $\begin{array}{l}\downarrow: \text { NOx, Smoke } \\
\uparrow: \mathrm{HC}, \mathrm{CO}\end{array}$ & [59] \\
\hline $\begin{array}{l}\text { 1-cylinder, } 4 \mathrm{~S} \text {, } \\
\text { CI, CR: } 19: 1, \\
\text { RP: } 11 \mathrm{~kW}, \mathrm{RS}: \\
3000 \mathrm{rpm}\end{array}$ & $\begin{array}{l}\text { Variable speed } \\
\text { and different loads }\end{array}$ & $\uparrow:$ BSFC & $\begin{array}{l}\downarrow: \text { NOx, Smoke } \\
\uparrow: \mathrm{HC}, \mathrm{CO}\end{array}$ & {$[60]$} \\
\hline
\end{tabular}

\section{HC Emission}

Hydrocarbons (HC) in the exhaust exist for one of two reasons: either from fuel that avoids combustion or from intermediate species of hydrocarbons that are formed during combustion and not completely combusted. The formation of hydrocarbons is typically due to local flame extinction, either by misfire or gaps in the cylinder geometry [15]. Since HCCI engines are lean (excess amounts of oxygen), hydrocarbons generally burn to completion except during misfire (or partial burn) conditions at later combustion timings. The HC present in the exhaust of HCCI engines usually comes from the 
crevices inside the cylinder, especially the area created near the walls by the piston rings. HCCI engines usually produce a higher rate of $\mathrm{HC}$ than conventional CI engines. From Table 2 it is seen that using diesel in an HCCI engine gives always higher HC. This enormous rate of $\mathrm{HC}$ can be reduced to some extent by blending diesel with biodiesel. Table 3 shows that in some cases the HC production rate is less than in $\mathrm{CI}$ engines.

Table 3. Different experimental engine performance and emission results using biodiesel-diesel blend in HCCI engine compared to CI engine

\begin{tabular}{|c|c|c|c|c|c|c|}
\hline Engine & $\begin{array}{l}\text { Test } \\
\text { condition }\end{array}$ & Biodiesel (\%) & $\begin{array}{l}\text { Reference } \\
\text { fuel }\end{array}$ & Performance & Emission & Reference \\
\hline $\begin{array}{l}\text { 2-cylinder, } \\
\text { 4S, AC, CI, } \\
\text { DI, CR: } \\
\text { 16.5:1, RP: } \\
\text { 5.85 kW, } \\
\text { RS: } 1500 \\
\text { rpm }\end{array}$ & $\begin{array}{l}\text { Constant } \\
\text { speed, } \\
\text { different } \\
\text { loads and } \\
\text { different } \\
\text { percentages } \\
\text { of EGR } \\
(0 \%, 15 \% \\
\text { and } 30 \%)\end{array}$ & $\begin{array}{l}20 \\
40\end{array}$ & Diesel & $\begin{array}{l}\downarrow: \text { ITE, } \\
\text { ISFC, heat } \\
\text { release } \\
\uparrow: \text { Cylinder } \\
\text { pressure }\end{array}$ & $\begin{array}{l}\downarrow: \mathrm{NOx} \uparrow: \\
\text { HC, CO, } \\
\text { Smoke }\end{array}$ & {$[61]$} \\
\hline $\begin{array}{l}\text { 1-cylinder, } \\
\text { 4S, NA, CI, } \\
\text { DI, CR: } \\
18.4: 1\end{array}$ & $\begin{array}{l}\text { Constant } \\
\text { speed, } \\
\text { different } \\
\text { loads and } \\
\text { different } \\
\text { percentages } \\
\text { of EGR } \\
(0 \% \text {, } \\
11.5 \% \text {, } \\
16.6 \% \text { and } \\
24.3 \%)\end{array}$ & $\begin{array}{l}30 \\
65\end{array}$ & Diesel & $\begin{array}{l}\downarrow: \text { Cylinder } \\
\text { pressure } \uparrow: \\
\text { Heat release }\end{array}$ & $\begin{array}{l}\downarrow: \text { Smoke } \\
\uparrow: \mathrm{HC}, \mathrm{CO}, \\
\mathrm{NOx}\end{array}$ & {$[62]$} \\
\hline $\begin{array}{l}\text { 1-cylinder, } \\
\text { 4S, CI, DI, } \\
\text { CR: 17.5:1 } \\
\text { RS: } 1500 \\
\text { rpm }\end{array}$ & $\begin{array}{l}\text { Constant } \\
\text { speed and } \\
\text { fixed load }\end{array}$ & ---- & Diesel & $\begin{array}{l}\text { —: Cylinder } \\
\text { pressure, } \\
\text { heat release }\end{array}$ & $\begin{array}{l}\downarrow: \mathrm{NOx}, \\
\mathrm{HC}, \mathrm{PM}, \\
\text { soot } \\
\uparrow: \mathrm{CO}\end{array}$ & {$[63]$} \\
\hline $\begin{array}{l}\text { 4-cylinder, } \\
\text { 4S, CI, IDI, } \\
\text { CR: 16.5:1 }\end{array}$ & $\begin{array}{l}\text { Constant } \\
\text { speed and } \\
\text { different } \\
\text { loads }\end{array}$ & ---- & Diesel & $\begin{array}{l}\uparrow: \mathrm{B} \text { SFC, } \\
\mathrm{BTE}\end{array}$ & $\begin{array}{l}\downarrow: \mathrm{NOx}, \\
\mathrm{HC} \\
\uparrow: \mathrm{CO}\end{array}$ & [49] \\
\hline $\begin{array}{l}\text { 1-cylinder, } \\
\text { 4S, CI, DI, } \\
\text { CR: } 17.5: 1 \\
\text { RP: } 4.4 \mathrm{~kW} \\
\text { RS: } 1500 \\
\text { rpm }\end{array}$ & $\begin{array}{l}\text { Constant } \\
\text { speed, } \\
\text { different } \\
\text { loads and } \\
\text { different } \\
\text { percentages } \\
\text { of EGR } \\
(0 \%, 10 \% \text {, } \\
20 \% \text { and } \\
30 \%)\end{array}$ & ---- & Diesel & $\begin{array}{l}\downarrow: \text { Heat } \\
\text { release } \\
\uparrow: \text { Cylinder } \\
\text { pressure }\end{array}$ & $\begin{array}{l}\downarrow: \text { NOx, } \\
\text { Smoke } \\
\uparrow: \mathrm{HC}, \mathrm{CO}\end{array}$ & [64] \\
\hline $\begin{array}{l}\text { 1-cylinder, } \\
\text { 4S, CI, DI, } \\
\text { CR: } 16: 1\end{array}$ & $\begin{array}{l}\text { Variable } \\
\text { speed and } \\
\text { different } \\
\text { loads }\end{array}$ & ---- & Diesel & $\begin{array}{l}\downarrow: \text { Heat } \\
\text { release } \\
\uparrow: \text { Ignition } \\
\text { delay }\end{array}$ & ---- & {$[65]$} \\
\hline
\end{tabular}




\section{CO Emission}

$\mathrm{CO}$ is mainly produced due to incomplete combustion of the fuel. Incomplete combustion occurs when the flame temperature cools down and progression to $\mathrm{CO}_{2}$ remains incomplete. When the flame front approaches a relatively cool cylinder liner and in crevice volume, the combustion process is slowed down and the flame front is extinguished. If the air-fuel mixture is too rich the amount of oxygen becomes insufficient for complete combustion. HCCI engines usually produce a higher rate of $\mathrm{CO}$ than conventional CI engines. From Table 2 it is seen that using diesel in HCCI engines always produces higher $\mathrm{CO}$. This enormous rate of $\mathrm{CO}$ can be reduced to some extent by blending diesel with biodiesel. Table 3 shows that in some cases the $\mathrm{CO}$ production rate is less than $\mathrm{CI}$ engines.

\section{Particulate Matter}

Particulate matter [18] emissions differ from unburned hydrocarbons as they are large agglomerations of smaller $\mathrm{HC}$ molecules formed in the combustion process. PM manifests itself as "soot" or "smoke" and is common in diesel engines. The formation of PM occurs in fuel-rich zones, whereas the oxidation of these particles occurs in the fuellean regions. Characterization generally consists of two different categories, PM10 and PM2.5, where the numeral indicates the maximum diameter of the PM molecule. Therefore, PM10 includes all particles consisting of a diameter less than 10 micrometers. Measurement of PM is done by taking advantage of different collection mechanisms including filtering, interception, impaction, and diffusion. In HCCI engines, the lean operation leads to negligible amounts of PM. Most of the literature reviewed in this paper showed a decreased amount of smoke and soot emission in HCCI engines.

\section{CONCLUSIONS}

There is enormous potential for HCCI in the energy sector, as engine producers cannot ignore the emissions and efficiency benefits. The ability to adapt to the alternative (nonpetroleum) fuel movement will also have a significant impact on the combustion engines of the future. It can be clearly seen that the HCCI engine has low emissions levels of NOx, soot and particulates. However, HCCI engines still have unresolved issues which are the high levels of unburned $\mathrm{HC}$ and $\mathrm{CO}$ emissions. As long as the current energy consumption trends continue and environmental sustainability remains a priority, the energy sector will experience major changes in the near-to-intermediate future. HCCI will most likely play a major role in this revolution, with the extent being defined by our success in addressing the issues highlighted above.

\section{ACKNOWLEDGEMENTS}

The authors would like to thank Universiti Malaysia Pahang and financial support under project no. RDU1403126 and postgraduate research grant scheme (GRS140381). 


\section{REFERENCES}

[1] Mohanamurugan S, Sendilvelan S. Emission and combustion characteristics of different fuel In A HCCI engine. International Journal of Automotive and Mechanical Engineering. 2011;3:279-92.

[2] Hairuddin AA, Wandel AP, Yusaf T. An Introduction to a Homogeneous Charge Compression Ignition Engine. Journal of Mechanical Engineering and Sciences. 2014;7:1042-52.

[3] Raitanapaibule K, Aung K. Performance predictions of a hydrogen-enhanced natural gas HCCI engine. ASME 2005 International Mechanical Engineering Congress and Exposition: American Society of Mechanical Engineers; 2005. p. 289-94.

[4] Epping K, Aceves S, Bechtold R, Dec J. The potential of HCCI combustion for high efficiency and low emissions. SAE Technical Paper; 2002.

[5] Christensen M, Johansson B. Influence of mixture quality on homogeneous charge compression ignition. SAE Technical Paper; 1998.

[6] Kong SC, Reitz RD. Use of detailed chemical kinetics to study HCCI engine combustion with consideration of turbulent mixing effects. Journal of Engineering for Gas Turbines and Power. 2002;124:702-7.

[7] Najt PM, Foster DE. Compression-ignited homogeneous charge combustion. SAE Technical Paper; 1983.

[8] Kong SC, Reitz RD. Numerical study of premixed HCCI engine combustion and its sensitivity to computational mesh and model uncertainties. Combustion Theory and Modelling. 2003;7:417-33.

[9] Soylu S. Examination of combustion characteristics and phasing strategies of a natural gas HCCI engine. Energy Conversion and Management. 2005;46:10119.

[10] Killingsworth NJ, Aceves SM, Flowers DL, Krstic M. A simple HCCI engine model for control. Computer Aided Control System Design, 2006 IEEE International Conference on Control Applications, 2006 IEEE International Symposium on Intelligent Control; 2006. p. 2424-9.

[11] Mack JH, Aceves SM, Dibble RW. Demonstrating direct use of wet ethanol in a homogeneous charge compression ignition (HCCI) engine. Energy. 2009;34:782-7.

[12] Abdullah NR, Shahruddin NS, Mamat R, Ihsan Mamat AM, Zulkifli A. Effects of air intake pressure on the engine performance, fuel economy and exhaust emissions of a small gasoline engine. Journal of Mechanical Engineering and Sciences. 2014;6:949-58.

[13] Sai Yashwanth M, Venugopal T, Ramesh A. Experimental and simulation studies to determine the effective Octane number in an engine fuelled with Ethanol and Gasoline. International Journal of Automotive and Mechanical Engineering. 2014;10:2057-69.

[14] Christensen M, Johansson B, Amnéus P, Mauss F. Supercharged homogeneous charge compression ignition. SAE Technical Paper; 1998.

[15] Warnatz J, Maas U, Dibble RW. Combustion: physical and chemical fundamentals, modeling and simulation, experiments, pollutant formation: Springer; 2006. 
[16] Swami Nathan S, Mallikarjuna J, Ramesh A. An experimental study of the biogas-diesel HCCI mode of engine operation. Energy Conversion and Management. 2010;51:1347-53.

[17] Yap D, Peucheret S, Megaritis A, Wyszynski M, Xu H. Natural gas HCCI engine operation with exhaust gas fuel reforming. International Journal of Hydrogen Energy. 2006;31:587-95.

[18] Laurens N, Koolwijk P, De Maat M. Fibrin structure and wound healing. Journal of Thrombosis and Haemostasis. 2006;4:932-9.

[19] Kuti OA, Zhu J, Nishida K, Wang X, Huang Z. Characterization of spray and combustion processes of biodiesel fuel injected by diesel engine common rail system. Fuel. 2013;104:838-46.

[20] Alptekin E, Canakci M. Characterization of the key fuel properties of methyl ester-diesel fuel blends. Fuel. 2009;88:75-80.

[21] Tesfa B, Mishra R, Gu F, Powles N. Prediction models for density and viscosity of biodiesel and their effects on fuel supply system in CI engines. Renewable Energy. 2010;35:2752-60.

[22] Kalam M, Husnawan M, Masjuki H. Exhaust emission and combustion evaluation of coconut oil-powered indirect injection diesel engine. Renewable Energy. 2003;28:2405-15.

[23] Lee SB, Han KH, Lee JD, Hong IK. Optimum process and energy density analysis of canola oil biodiesel synthesis. Journal of Industrial and Engineering Chemistry. 2010;16:1006-10.

[24] Arbab M, Masjuki H, Varman M, Kalam M, Imtenan S, Sajjad H. Fuel properties, engine performance and emission characteristic of common biodiesels as a renewable and sustainable source of fuel. Renewable and Sustainable Energy Reviews. 2013;22:133-47.

[25] Shahir S, Masjuki H, Kalam M, Imran A, Fattah I, Sanjid A. Feasibility of diesel-biodiesel-ethanol/bioethanol blend as existing CI engine fuel: An assessment of properties, material compatibility, safety and combustion. Renewable and Sustainable Energy Reviews. 2014;32:379-95.

[26] De Almeida SC, Belchior CR, Nascimento MV, Vieira LdS, Fleury G. Performance of a diesel generator fuelled with palm oil. Fuel. 2002;81:2097102.

[27] Machacon HT, Shiga S, Karasawa T, Nakamura H. Performance and emission characteristics of a diesel engine fueled with coconut oil-diesel fuel blend. Biomass and Bioenergy. 2001;20:63-9.

[28] Bari S, Lim T, Yu C. Effects of preheating of crude palm oil (CPO) on injection system, performance and emission of a diesel engine. Renewable Energy. 2002;27:339-51.

[29] Nwafor O. The effect of elevated fuel inlet temperature on performance of diesel engine running on neat vegetable oil at constant speed conditions. Renewable Energy. 2003;28:171-81.

[30] Amini-Niaki SR, Ghazanfari A. Comparison of fuel and emission properties of petro diesel and sunflower biodiesel prepared by optimized production variables. Fuel. 2013;109:384-8.

[31] Martínez PE. Termodinámica básica y aplicada1984.

[32] Srivastava A, Prasad R. Triglycerides-based diesel fuels. Renewable and sustainable energy reviews. 2000;4:111-33. 
[33] Benjumea P, Agudelo J, Agudelo A. Basic properties of palm oil biodieseldiesel blends. Fuel. 2008;87:2069-75.

[34] Tat ME, Van Gerpen JH. The kinematic viscosity of biodiesel and its blends with diesel fuel. Journal of the American Oil Chemists' Society. 1999;76:1511-3.

[35] Chen LY, Chen YH, Hung YS, Chiang TH, Tsai CH. Fuel properties and combustion characteristics of jatropha oil biodiesel-diesel blends. Journal of the Taiwan Institute of Chemical Engineers. 2013;44:214-20.

[36] Shang Q, Jiang W, Lu H, Liang B. Properties of Tung oil biodiesel and its blends with diesel. Bioresource Technology. 2010;101:826-8.

[37] Joshi RM, Pegg MJ. Flow properties of biodiesel fuel blends at low temperatures. Fuel. 2007;86:143-51.

[38] Al-Hamamre Z, Al-Salaymeh A. Physical properties of (jojoba oil+biodiesel), (jojoba oil+diesel) and (biodiesel+diesel) blends. Fuel. 2014;123:175-88.

[39] Pinto AC, Guarieiro LL, Rezende MJ, Ribeiro NM, Torres EA, Lopes WA, et al. Biodiesel: an overview. Journal of the Brazilian Chemical Society. 2005;16:1313-30.

[40] Knothe G. Dependence of biodiesel fuel properties on the structure of fatty acid alkyl esters. Fuel Processing Technology. 2005;86:1059-70.

[41] Gumus M. A comprehensive experimental investigation of combustion and heat release characteristics of a biodiesel (hazelnut kernel oil methyl ester) fueled direct injection compression ignition engine. Fuel. 2010;89:2802-14.

[42] Benjumea P, Agudelo J, Agudelo A. Effect of altitude and palm oil biodiesel fuelling on the performance and combustion characteristics of a HSDI diesel engine. Fuel. 2009;88:725-31.

[43] Tesfa B, Mishra R, Zhang C, Gu F, Ball AD. Combustion and performance characteristics of CI (compression ignition) engine running with biodiesel. Energy. 2013;51:101-15.

[44] Payri F, Lujan J, Martin J, Abbad A. Digital signal processing of in-cylinder pressure for combustion diagnosis of internal combustion engines. Mechanical Systems and Signal Processing. 2010;24:1767-84.

[45] Desantes J, Galindo J, Guardiola C, Dolz V. Air mass flow estimation in turbocharged diesel engines from in-cylinder pressure measurement. Experimental Thermal and Fluid Science. 2010;34:37-47.

[46] Banapurmath N, Tewari P, Hosmath R. Performance and emission characteristics of a DI compression ignition engine operated on Honge, Jatropha and sesame oil methyl esters. Renewable Energy. 2008;33:1982-8.

[47] Karim G, Jones W, Raine R. An examination of the ignition delay period in dual fuel engines. SAE Technical Paper; 1989.

[48] Fathi M, Khoshbakhti Saray R, David Checkel M. Detailed approach for apparent heat release analysis in HCCI engines. Fuel. 2010;89:2323-30.

[49] Mohanamurugan S, Sendilvelan. Emission and combustion characteristics of different fuel in HCCI engine. International Journal of Automotive and Mechanical Engineering. 2011;3:279-92.

[50] EPA-Gasoline R. Regulatory Impact Analysis - Control of Air Pollution from New Motor Vehicles: Tier 2 Motor Vehicle Emissions Standards and Gasoline Sulfur Control Requirements, US Environmental Protection Agency, Air and Radiation. US Environmental Protection Agency, Air and Radiation EPA420. 1999. 
[51] Wesselink L, Buijsman E, Annema J. The impact of Euro 5: facts and figures. The Netherlands. 2006.

[52] Popp D. International innovation and diffusion of air pollution control technologies: the effects of $\mathrm{NOx}$ and $\mathrm{SO}_{2}$ regulation in the US, Japan, and Germany. Journal of Environmental Economics and Management. 2006;51:4671.

[53] Rizvi SQ. Lubricant Chemistry, Technology, Selection, and Design: West Conshohocken: ASTM International; 2009.

[54] Ganesh D, Nagarajan G, Mohamed Ibrahim M. Study of performance, combustion and emission characteristics of diesel homogeneous charge compression ignition (HCCI) combustion with external mixture formation. Fuel. 2008;87:3497-503.

[55] Singh AP, Agarwal AK. Combustion characteristics of diesel HCCI engine: An experimental investigation using external mixture formation technique. Applied Energy. 2012;99:116-25.

[56] Ganesh D, Nagarajan G. Homogeneous charge compression ignition (HCCI) combustion of diesel fuel with external mixture formation. Energy. 2010;35:148-57.

[57] Thompson JC, Peterson CL, Taberski IS. One-thousand-hour engine durability test with HySEE and using a 5X-EMA test cycle. Transactions of the ASAE. 1999;

[58] Guo H, Hosseini V, Neill WS, Chippior WL, Dumitrescu CE. An experimental study on the effect of hydrogen enrichment on diesel fueled HCCI combustion. International Journal of Hydrogen Energy. 2011;36:13820-30.

[59] Shi L, Cui Y, Deng K, Peng H, Chen Y. Study of low emission homogeneous charge compression ignition (HCCI) engine using combined internal and external exhaust gas recirculation (EGR). Energy. 2006;31:2665-76.

[60] Kim MY, Lee CS. Effect of a narrow fuel spray angle and a dual injection configuration on the improvement of exhaust emissions in a HCCI diesel engine. Fuel. 2007;86:2871-80.

[61] Singh G, Singh AP, Agarwal AK. Experimental investigations of combustion, performance and emission characterization of biodiesel fuelled HCCI engine using external mixture formation technique. Sustainable Energy Technologies and Assessments. 2014;6:116-28.

[62] Jiménez-Espadafor FJ, Torres M, Velez JA, Carvajal E, Becerra JA. Experimental analysis of low temperature combustion mode with diesel and biodiesel fuels: A method for reducing NOx and soot emissions. Fuel Processing Technology. 2012;103:57-63.

[63] Mancaruso E, Vaglieco B. Optical investigation of the combustion behaviour inside the engine operating in HCCI mode and using alternative diesel fuel. Experimental Thermal and Fluid Science. 2010;34:346-51.

[64] Ganesh D, Nagarajan G, Ganesan S. Experimental Investigation of Homogeneous Charge Compression Ignition Combustion of Biodiesel Fuel with External Mixture Formation in a CI engine. Environmental Science \& Technology. 2014;48:3039-46.

[65] Zhang S, Broadbelt LJ, Androulakis IP, Ierapetritou MG. Comparison of biodiesel performance based on HCCI engine simulation using detailed mechanism with on-the-fly reduction. Energy and Fuels. 2012;26:976-83. 